\title{
PENTINGNYA TEORI AKUNTANSI SYARI'AH \\ PERSPEKTIF AKUNTANSI SOSIAL DAN PERTANGGUNGJAWABAN BISNIS SYARIAH
}

\author{
Hendrarto Widodo ${ }^{{ }^{*}}$ \\ ${ }^{1}$ Mahasiswa Pascasarjana Fakultas Ekonomi Universitas Jember \\ *jhon_hendra_09@yahoo.co.id
}

\begin{abstract}
:
This paper discusses the Islamic perspective of accounting, known as sharia accounting. The accounting sharia based on the Qur'an and Hadith, both on paradigms and practices. It is not only a social orientation but also the orientation of the responsibility. The accounting sharia will report the social impacts of an activity and responsibility of humanistic, emancipatory, transcendental and theological. In Islamic terminology, accounting sharia is zakat and amanah oriented.
\end{abstract}

Keywords: Islamic Accounting, Social Responsibility, Zakat

\section{PENDAHULUAN}

Pada akhir - akhir ini nilai-nilai agama telah dijadikan pijakan dalam pengembangan dan pelaksanaan aktivitas bisnis, sehingga bisnis diharapkan tidak meninggalkan etika. Dalam Islam, seluruh etika yang dijadikan kerangka bisnis, dibangun atas dasar Syariah. Syariah merupakan pedoman yang digunakan oleh umat Islam untuk berperilaku dalam segala aspek kehidupan. Bagi umat Islam, kegiatan bisnis (termasuk bisnis perbankan) tidak akan pernah terlepas dari ikatan etika Syariah.

Maka dari itu, bukan hal yang berlebihan bila, sebagai contoh bank Islam beroperasi berdasarkan pada nilai etika Syariah. Bahkan secara formal bank Islam membentuk suatu badan khusus dalam organisasinya. Badan ini bertugas memberikan pandangan dasar-dasar etika (atau pengawasan) Syariah bagi manajemen dalam menjalankan operasi bank (termasuk pencatatan dan pelaporan akuntansinya). Badan tersebut dinamakan Dewan Pengawas Syariah yang berdiri secara tidak tergantung pada bagian bank lainnya (independent) di dalam organisasi bank.

Dalam wilayah pembangunan ekonomi umat, keberadaan dan kehadiran lembaga bisnis, seperti lembaga keuangan syariah adalah mutlak adanya. Sebab perbankan bertindak sebagai perantara (intermediary) antara unit penawaran (supply) dengan unit permintaan (demand). Disinilah diperlukan proses pencatatan dan pelaporan semua transaksi dan kegiatan muamalah yang dilakukan di unit bisnis. Oleh karena itu, diperlukan sistem akuntansi yang sesuai (relevan). Sehubungan dengan itu, perlu pula adanya proses akuntansi. Proses akuntansi ini tidak saja akan mempengaruhi perilaku manajemen, pemegang saham, karyawan, dan masyarakat sekelilingnya, tetapi juga organisasi yang bersangkutan.

Selain itu faktor lain seperti sistem ekonomi, sosial, politik, peraturan perundangundangan, kultur, persepsi, dan nilai yang berlaku dalam masyarakat mempunyai pengaruh besar terhadap bentuk akuntansi. Hal ini membuktikan bahwa akuntansi adalah sebuah keutuhan (entitas/entity) informasi yang tidak bebas nilai.

Sehubungan dengan hal di atas, Baswir menyatakan bahwa: "munculnya kesan bahwa akuntansi juga memiliki kaitan dengan ideologi sulit untuk dielakkan, dan akuntansi seperti yang saat ini diajarkan pada jurusan - jurusan akuntansi di Indonesia, ternyata sangat kuat dipengaruhi oleh kapitalisme. Pengaruh kapitalisme itu terutama tampak sangat nyata pada kuatnya 
pengaruh prinsip ekonomi kapitalistik dalam penyajian laporan pendapatannya.

Dengan demikian, apabila suatu negara mengikuti Sistem Ekonomi Islam maka upaya yang harus dikembangkan adalah Sistem Akuntansi Islam (Syariah). Namun perlu disadari bahwa anggapan terhadap keberadaan akuntansi Syariah (Islam) masih banyak dipertanyakan orang. Lahirnya akuntansi Syariah adalah setelah adanya anggapan kurang yakin terhadap keberadaan akuntansi konvensional sebagai ilmu pengetahuan dan pelaksanaannya dalam kaitannya dengan persoalan nilai dalam akuntansi.

Dalam persepsi Islam, manusia di muka bumi adalah sebagai khalifah. Oleh karena itu, seluruh upaya yang dilakukan oleh manusia harus mampu menjawab kebutuhan masyarakat atau harus berorientasi sosial. Demikian pula upaya kita untuk mengembangkan akuntansi syariah. Akuntansi harus berkembang dengan menjawab kebutuhan masyarakat.

Islam melalui al-Qur'an telah menggariskan bahwa konsep akuntansi yang harus diikuti oleh para pelaku bisnis atau pembuatan laporan akuntansi menekankan pada konsep pertanggungjawaban atau accountability, sebagaimana ditegaskan dalam Surat al-Baqarah ayat 282. Disamping itu, akuntansi Syariah harus berorientasi sosial. Hal ini berarti, bahwa akuntansi tidak hanya sebagai alat untuk menterjemahkan fenomena ekonomi dalam bentuk ukuran moneter tetapi juga sebagai suatu metode untuk menjelaskan tentang bagaimana fenomena ekonomi itu berjalan dalam masyarakat (Islam).

Berdasarkan latar belakang masalah di atas, maka permasalahan dalam artikel ini dirumuskan sebagai berikut:

a. Bagaimanakah hakekat akuntansi syariah dilihat dari perspektif akuntansi sosial dan pertanggungjawaban?,

b. Apakah akuntansi itu merupakan suatu bentuk pengetahuan dan praktik yang banyak ditentukan oleh lingkungannya (non value-free), atau dengan kata lain, apakah akuntansi adalah "anak" yang lahir dari budaya setempat (lokal)?

\section{METODE}

Upaya rasional, penentuan kebenaran hakikat dan eksistensi akuntansi syariah perlu diteliti dengan metode penelitian yang tepat. Ketepatan metode penelitian tersebut akan tercermin pada tahap-tahap penelitian yang dilalui.

Penulisan artikel ini dilakukan untuk menemukan rasionalitas dan kebenaran hakikat, pengetahuan dan praktik akuntansi, maka kajian teori kritis akan digunakan, yang penerapannya dilakukan melalui dua tahapan, yaitu: tahap deskriptif dan tahap evaluatif/kritik. Kedua tahap kajian ini masing-masing menggunakan metode yang berbeda, sesuai dengan esensi permasalahan artikel ini.

Pada tahap reduksi penulis mengarahkan pada pokok-pokok masalah yang telah diajukan dengan menggunakan kerangka dasar filsafat ilmu. Berpijak dari filsafat ilmu inilah, maka kerangka bangun hakekat akuntansi syariah dapat dilihat dari sisi: ontologi; epistimologi, metodologi dan aksiologi, sehingga sasaran dan orientasi bangun akuntansi syariah dapat terwujud. Dimaksud dengan bangun akuntansi syariah tersebut diantaranya adalah bangun akuntansi yang merefleksikan dimensi sosial dan pertanggungjawaban.

Ontologi menyangkut tentang hakekat apa yang dikaji atau science of being qua being Epistimologi adalah berkaitan dengan bagaimana cara ilmu pengetahuan melakukan pengkajian dan menyusun tubuh pengetahuannya atau studi filsafat yang membahas ruang lingkup dan batas-batas pengetahuan. Metodologi digunakan untuk menguji metode - metode yang digunakan atau yang akan digunakan untuk menghasilkan pengetahuan yang valid. Sementara aksiologi adalah tiang penyangga filsafat ilmu yang berkaitan dengan kegunaan ilmu yang telah tersusun itu dipergunakan atau theory of value.

Berdasarkan tiga sisi tersebut selanjutnya dapat dilakukan analisis terhadap esensi ilmu pengetahuan. Walaupun harus disadari bahwa sebagai bahan untuk mengkaji Akuntansi Syariah (Islam) maka 
jalan terbaik yang ditempuh adalah mempelajari Akuntansi Barat yang sudah demikian mapan dan berkembang, bahkan telah dianut baik oleh masyarakat Barat maupun masyarakat muslim.

Suatu badan usaha/organisasi/lembaga baik yang bertujuan mencari laba maupun nirlaba (non-profit) membutuhkan informasi untuk proses pengambilan keputusan dan pengembangan perusahaan. Pada sisi inilah akuntansi berperan. Akuntansi merupakan bagian yang tidak terpisahkan dari suatu gugusan tugas manajemen dalam mencapai tujuannya. Akuntansi akan memberikan informasi yang sangat dibutuhkan manajemen dalam melaksanakan fungsi-fungsinya, yaitu: Perencanaan; Pengorganisasian; Pengarahan; dan Pengawasan.

\section{Tahap Evaluatif}

Metode yang digunakan pada tahap evaluatif adalah metode analitik kritis-rasional. Metode ini diterapkan mengingat pada tahap ini dilakukan upaya membandingkan konsep Akuntansi Barat dengan konsep Akuntansi Syariah. Seperti halnya dalam upaya mengkaji atau membangun teori sosial, termasuk teori akuntansi, maka proses berfikir analisis: kritis dan rasional sangat dituntut. Dalam penelitian akuntansi, pendekatan kritis (critical studies) merupakan salah satu pendekatan yang disarankan untuk diterapkan.

Sehubungan dengan perkembangan sistem ekonomi baru, yaitu sistem ekonomi Islam, tentu saja kondisi ini menuntut relevansi seluruh instrumen, model, sistem dan paradigma akuntansi. Dengan kata lain, kondisi ini harus dibarengi dengan munculnya keterbukaan dan kesadaran para ilmuwan untuk menemukan dan mengembangan ilmu baru yang sesuai dengan disiplin yang ada. Oleh karena itu, Cooper dan Hopper menyatakan bahwa: “... critical accounting is critical of convetional accounting theory and practice and, through critical social science theory, it seeks to explain how the current state of accounting has come about".

Pernyataan ini menandakan betapa pentingkan critical theory dalam rangka membangun suatu teori baru yang sesuai (relevan) dengan perkembangan masyarakat. Bagaimana kerangka kerja yang akan ditempuh apabila kita menggunakan pendekatan critical theory? Pada tataran yang lebib luas, menurut Lodh disarankan, bahwa: "... an accounting researcher can ask: what, how and why accounting rationale has become purposive, is being used, is to be used, and what are the means for doing so in a particular context?

Melalui pendekatan critical theory kita akan melihat suatu teori itu bukan saja terletak pada upaya menempatkan ideologi sebagai 'bentuk pemikiran' akan tetapi juga akan mencoba mengkaji tentang bagaimana kondisi sosial, seperti sistem akuntansi yang dikembangkan oleh kaum kapitalis, terpenuhinya kepuasan kebutuhan hidup, dan kebebasan diri dari kondisi sosial masyarakat yang rentan.

Berdasarkan uraian di atas, maka melalui pendekatan critical theory ini akan mampu menemukan kerangka rasional hakikat dan penerapan teori akuntansi yang lebih sesuai dengan budaya lokal Islam, yang sarat dengan nilai. Dengan kata lain, pendekatan yang diterapkan dalam penelitian ini harus dimapankan sebagai: " $a$ process which can be used for analysing and changing the nature of any accounting system, and its social context, of any particular organisation". Artinya, suatu proses yang dapat digunakan untuk menganalisis dan mengubah hakikat sistem akuntansi dalam hubungannya dengan kondisi sosial atau organisasi tertentu.

\section{Metode Pengumpulan Data}

Sesuai dengan pendekatan yang digunakan dalam penelitian ini, maka data yang digunakan adalah berupa pernyataanpernyataan ahli yang relevan. Dengan demikian teknik pengambilan sampel data adalah dengan purposive sampling/data, yang selanjutnya didukung dengan teknik analisis isi (content analysis). Teknik ini menurut Bogdan dan Biklen (1982) yang dikutip Syafi'ie dimaksudkan untuk pengambilan sampel internal (internal sampling). Internal 
sampling yaitu keputusan yang diambil, begitu peneliti memiliki suatu pikiran umum tentang jumlah dokumen serta macamnya yang akan dikaji, dengan siapa akan berbicara, dan kapan akan melakukan observasi.

Penggalian data primer mula-mula dilakukan dengan mengumpulkan ayat-ayat yang berkaitan dengan istilah perhitungan (hisab), keseimbangan, pertanggungjawaban, kemudian membuat outline dalam rangka menentukan ayat-ayat yang secara langsung berkaitan dengan ayat-ayat yang tidak secara langsung mengungkap tentang hisab, yang dalam penggaliannya menggunakan teknik dokumentasi murni. Sedangkan untuk mengumpulkan data sekunder dilakukan dengan mencari pokok-pokok pikiran yang ditulis oleh para pemikir atau ilmuwan yang telah ditulis dalam buku - buku terutama yang berkaitan dengan tema sentral yang telah diajukan, dalam rangka menemukan esensi tentang konsep akuntansi.

\section{Teknik dan Model Analisis}

Dalam penelitian kualitatif, pada tahap analisis setidak-tidaknya ada tiga komponen pokok yang harus disadari oleh peneliti, yaitu: data reduction, data display dan conclusion drawing (Miles \& Huberman, 1984; Sutopo, 1988). Tiga komponen tersebut saling berhubungan dan saling mendukung.

Sehubungan dengan permasalahan akuntansi maka Gaffikin menyarankan empat tahapan yang harus dilalui oleh peneliti dalam menerapkan metodologi analisis. Keempat tahapan tersebut adalah: Logical, Environmental, Ideological dan Linguistic.

\section{PEMBAHASAN}

\section{Hisab, Muhasabah Dan Akuntansi}

Syariah Islam adalah syari'at yang memberikan perhatian besar terhadap masalah hisab Hisab adalah salah satu proses perhitungan amal selama hidup manusia di dunia oleh Allah. Sebagai khalifah, manusia diberikan amanah oleh Allah untuk mengelola bumi yang kemudian hasilnya dipertanggungjawabkan kepadaNya. Oleh karena itu, setiap manusia dalam hidupnya harus selalu dalam keadaan amanah, jujur dan komitmen tinggi terhadap janji yang telah diucapkan kepada Allah. Hal demikian ini merupakan bagian dari perilaku manusia yang Islami. Sehubungan dengan ini, Ghamidi (1997) mengatakan bahwa: "perilaku yang Islami, adalah perilaku yang pelakunya, selalu merasakan adanya pengawasan oleh Allah baik dalam keadaan tersembunyi maupun terlihat orang dan selalu melakukan muhasaba (menghitung-hitung atau mengevaluasi) diri, terhadap kaum Muslimin maupun terhadap yang lain, merupakan jalan dakwah kepada Islam yang terbaik.

Oleh karena itu, kaum Muslimin harus kembali kepada Allah, mengoreksi diri mereka, menerapkan perilaku Islami dalam seluruh segi kehidupan, senantiasa jujur, iman dan qana'ah, agar kemuliaan dapat diraih kembali.

Berkaitan dengan kata muhasaba di atas, menurut Atiya dinyatakan, bahwa kata Arab yang berarti akuntansi adalah muhasabah (hisab). Kata ini muncul 48 kali dalam al- Qur'an. ${ }^{35}$ Sementara Muhammad Khir yang dikutip oleh Harahap disebutkan bahwa "Istilah hisab ditemukan 109 kali dalam al- Qur'an. Akar kata muhasabah adalah h.s.b dengan bentuk verbalnya hasaba dan bentuk lainnya yahsaba yang berarti mengitung (to compute) atau mengukur (to measure).

Lebih jauh perubahan kata hisab menjadi muhasaba adalah sebagai berikut AlMuhasaba berasal dari perubahan kata "alhisab", yaitu perhitungan. Dari segi bahasa, munculnya kata al-muhasabah terjadi karena adanya perubahan isim, yaitu hisab/hisaban atau hasaba sebagai isim masdar termasuk fiil madli, kemudian yuhasibu sebagai isim masdar mim termasuk dalam fiil mudhari'.

Penggunaan kata hisab akan mengalami perubahan sesuai dengan kontek dan bentuk kalimat. Sehingga hisab akan berubah menjadi hasaba, jika kalimat yang dibentuk berarti "selesaikan tanggung jawab" atau "agar netral". Kemudian akan berubah menjadi tahasaba yang berarti "menjaga" atau "mencoba mendapatkan." Juga dapat berubah menjadi ihtisaba yang berarti 
"mengharapkan pahala di akhirat dengan diterimanya kitab seseorang dari Tuhan", juga berarti "menjadikannya perhatian" atau "mempertanggung jawabkannya". Akhirnya dalam perkembangan selanjutnya, peristilahan kata bahasa Inggris berkembang secara etimologis, istilah Arab justru berkembang secara fonetis (suara), kata muhasabah (akuntansi) berkaitan dengan ihtisab dan citranya dikaitkan dengan pencatatan perbuatan seseorang secara terus menerus sampai pada pengadilan akhirat dan melalui timbangan (mizan) sebagai alat dan Tuhan sebagai akuntan.

Istilah lain yang memiliki makna sama dengan kata muhasaba adalah al-Hisba, namun kata al-hisbah menunjuk pada penerapan atau operasi suatu lembaga. Sehubungan dengan itu, Taymiyah menyebutnya, bahwa "al-Hisbah adalah lembaga publik yang telah ada pada masyarakat Islam sejak awal periode Islam sampai masa pendudukan Barat. Personil yang mengelola lembaga Hisba disebut muhtasib. Kegiatan lembaga ini mencakup tugas yang luas, yaitu mulai dari hal-hal yang bersifat ekonomi sampai pada yang bersifat etika.

Uraian di atas, menunjukkan bahwa kata hisab atau muhasaba dan pelaku muhasaba atau muhtasib adalah kata dan fungsi yang berkaitan dengan upaya untuk menghitung, mengukur atau mengendalikan seluruh aktivitas manusia selama hidup di dunia untuk dapat dipertanggungjawabkan di akhirat. Dengan demikian, muhtasib memiliki tugas yang sangat luas, dari pengawasan harta, yang menyangkut kepentingan sosial sampai pada pemeriksaan atas transaksi bisnis perusahaan.

Sebagaimana diuraikan di atas, bahwa di dalam al-Qur'an banyak ditemukan ayat yang menggunakan kata hisab yang dikaitkan dengan sifat dan fungsi hisab dari Allah kepada perbuatan manusia. Ayat-ayat inilah yang dijadikan nash tentang perhitungan amal perbuatan manusia selama hidup di dunia untuk dipertanggung-jawabkan di akhirat.

Lebih-lebih lagi, proses perdagangan atau transaksi di masa sekarang telah mengalami pergeseran. Artinya, budaya transaksi dengan sistem kredit saat ini banyak di lakukan di samping adanya transaksi perdagangan secara kontan (tunai). Dengan demikian, proses pencatatannya harus dilakukan untuk transaksi kredit maupun tunai. Oleh karena itu, setiap transaksi dalam berniaga seharusnya ditulis secara baik dan benar. Sebab hal demikian dapat menjadi informasi penting dalam melakukan aktivitas niaga pada masa- masa yang akan datang. Dengan melakukan penulisan terhadap semua transaksi, peminjam ataupun penjual akan lebih mudah mempertang- gungjawabkan niaganya. Hal inilah yang menjadi inti dari ayat 282 QS. Al-Baqarah tersebut di atas. Dengan demikian, mengacu pada uraian di atas, maka secara ringkas dapat dirumuskan prinsip umum akuntansi syariah sebagai berikut:

1) Keadilan

2) Kebenaran

3) Pertanggungjawaban

Berdasarkan tiga prinsip umum tersebut dan didukung dengan bentuk-bentuk praktis hisab yang tercantum dalam tiga puluh ayat di atas -yang akan dikenakan Allah kepada umat manusia, maka selanjutnya dapat ditemukan prinsip-prinsip khusus dalam akuntansi syariah. Oleh karenanya nilai keadilan, kebenaran dan pertanggungjawaban pencatatan transaksi dapat terwujud apabila pelaporan akuntansi dilakukan dengan: benar; cepat; terang, jelas, tegas dan informatif; menyeluruh; ditujukan kepada semua pihak; terperinci dan teliti; tidak terdapat unsur manipulasi; dan dilakukan secara kontinyu.

\section{Penyesuaian Teori Akuntansi Syariah}

Pembicaraan akuntansi syariah (Islam), akhir-akhir ini semakin sering kita dengar, baik di dalam negeri maupun di luar negeri, walaupun keberadaan akuntansi syariah itu sendiri seperti halnya dengan keberadaan Sistem Ekonomi Islam $\square$ masih dipertanyakan. Pembicaraan semacam itu muncul karena ilmu akuntansi yang dipelajari sampai saat ini masih tertuju dan merujuk pada sistem akuntansi Barat, yang didalamnya mengandung persoalan. Beberapa diantaranya adalah (1) 
persoalan kepemihakan, (2) asumsi atau basic concept, (3) efek dari persoalan basic concept tentu saja merembes ketingkat standar, atau bahkan metode akuntansi yang dipilih. Berangkat dari tiga persoalan dasar tersebut, maka semua asumsi, postulat, kaidah, dan prinsip-prinsip dalam akuntansi Barat dapat diterapkan untuk lembaga-lembaga atau perusahaan yang menegakkan nilai- nilai Islam. Oleh karena itu, perlu dirancang atau dibangun sistem, format akuntansi yang menegakkan nilai-nilai Islam.

Sesuai dengan topik ini, maka pembahasannya terfokus pada topik-topik sebagai berikut: Teori Akuntansi Syariah; dan Praktek Akuntansi Syariah, yang di dalamnya dibahas tentang refleksi akuntansi sosial dan pertanggungjawaban, dengan uraian sebagai berikut:

\section{Teori Akuntansi Syariah}

Ada suatu perubahan luar biasa dalam bidang ilmu akuntansi untuk beberapa dekade belakangan ini. Sebelum tahun 1970-an ada anggapan tentang akuntansi sebagai ilmu pengetahuan dan praktek yang bebas dari nilai (value-free) sudah mulai digoyang keberadaannya. Anggapan tersebut sejak lama mendominasi sebagian besar akuntan dan para peneliti di bidang akuntansi. Keadaan semacam ini semakin kuat karena adanya kecenderungan perilaku masyarakat yang terbawa oleh arus era informasi dan globalisasi.

Pada era informasi dan globalisasi dalam bidang akuntansi ada upaya harmonisasi praktek-praktek akuntansi. Hal ini berarti ada kehendak untuk memberlakukan praktek- praktek akuntansi secara seragam seluruh dunia. Dengan kata lain, nilai-nilai lokal praktek akuntansi, yang mungkin sangat berbeda dengan praktek dunia internasional, sedapat mungkin dieliminasi karena keberagaman praktek akuntansi di setiap negara dianggap menyulitkan dalam menafsirkan laporan keuangan, atau praktek akuntansi yang beragam itu tidak dapat diperbandingan (uncomparable).

Kasus ini mengundang reaksi banyak kalangan, sehingga muncullah pandangan- pandangan yang bersifat pro dan kontra. Mereka yang berpandangan kontra mengecam bahwa tindakan untuk melakukan harmonisasi merupakan tindakan pelecehan terhadap nilai-nilai lokal. Mereka justru melihat bahwa sebetulnya akuntansi adalah suatu bentuk pengetahuan dan praktek yang banyak ditentukan lingkungannya (non value-free). Bahkan ada yang mengatakan akuntansi adalah "anak" yang lahir dari budaya setempat (lokal).

Pandangan kedua, memang secara eksplisit menolak pandangan pertama yang bersifat fungsionalis dan positivistik, kalau ditelusuri ke belakang akar pemikiranya berasal dari August Comte. Pemikiran ini memiliki sifat reduksionis, yaitu menghilangkan kandungan nilai yang seharusnya terkandung dalam ilmu pengetahuan dan praktek akuntansi. Keringnya nilai ini menyebabkan masyarakat bisnis, ketidakseimbangan tatanan sosial, dan kerusakan lingkungan terjadi.

Berpijak dari kasus di atas, usaha untuk mencari bentuk akuntansi yang berwajah humanis, emansipatori, transendental, dan teleologikal merupakan upaya yang niscaya. Timbul pertanyaan, upaya apa yang harus dilakukan? Upaya ini secara filosofis dan metodologis dapat dilakukan dengan menggunakan meta perspektif, yaitu suatu pandangan yang berusaha berada di atas perspektif-perspektif yang ada. Karena dengan cara ini pandanganpandangan filosofis, seperti pandangan tentang hakekat manusia dan masyarakat, ontologi, epistimologi, aksiologi dan metodologi, menjadi lebih luas dan utuh, sehingga formulasi pengetahuan dan praktek akuntansi menjadi lebih humanis dan sarat dengan nilai.

Akuntansi syariah, menurut Iwan Triyuwono dan Gaffikin dikatakan, merupakan salah satu upaya mendekontruksi akuntansi modern ke dalam bentuk yang humanis dan sarat nilai. Tujuan diciptakannya akuntansi syariah adalah terciptanya peradaban bisnis dengan wawasan humanis, emansipatoris, transendental, dan teleologikal. Konsekuensi 
ontologis upaya ini adalah bahwa akuntan secara kritis harus mampu membebaskan manusia dari ikatan realitas peradaban, beserta jaringan-jaringan kuasanya, kemudian memberikan atau menciptakan realitas alternatif dengan seperangkat jaringanjaringan kuasa Ilahi yang mengikat manusia dalam hidup sehari-hari (ontologi tauhid).

Dengan cara demikian, realitas alternatif diharapkan akan dapat membangkitkan kesadaran diri secara penuh akan kepatuhan dan ketundukan seseorang kepada kuasa Allah. Dengan kesadaran diri tersebut, ia akan selalu merasakan kehadiran Tuhan dalam dimensi waktu dan tempat dimana ia berada. Dengan demikian, melalui akuntansi syariah, realitas sosial akan dirancang dan dibangun melalui muatan nilai tauhid dan ketundukan pada jaringanjaringan kuasa Ilahi. Kesemuanya itu dilakukan dengan perspektif khalifatullah fil $a r d h$. Perspektif ini berarti suatu cara pandang yang sadar akan hakikat diri manusia dan tanggung jawab kelak di kemudian hari di hadapan Allah SWT.

Oleh karena itu, akuntansi syariah adalah teori yang menjelaskan bagaimana mengalokasikan sumber-sumber yang ada secara adil bukan pelajaran tentang bagaimana akuntansi itu ada. Sehubungan dengan ini Shahata menjelaskan kemungkinan keberadaan akuntansi syariah sebagai berikut: "Postulat, standar, penjelasan dan prinsip akuntansi yang menggabarkan semua hal ... karenanya secara teoritis akuntansi memiliki konsep, prinsip, dan tujuan Islam dan semua ini secara serentak berjalan bersama bidang ekonomi, sosial, politik, ideologi, etika yang dimiliki Islam, kehidupan Islam dan keadilan dan hukum Islam. Dan Islam adalah suatu program yang memiliki bidang- bidang ekonomi, sosial, politik, ideologi, manajemen, akuntansi, dan lain-lain. Kesemua ini adalah satu paket yang tak bisa dipisah.

Dalam mencari bentuk akuntansi syariah, harus berangkat dari suatu asumsi bahwa akuntansi adalah sebuah entitas yang mempunyai dua arah kekuatan. Kekuatan pertama adalah bahwa akuntansi adalah sesuatu yang dibentuk oleh lingkungannya. Kekuatan kedua adalah bahwa akuntansi adalah sesuatu yang memiliki kekuatan untuk mempengaruhi lingkungannya, termasuk perilaku manusia yang menggunakan informasi akuntansi. Jika demikian, maka usaha yang harus dilakukan oleh para akuntan adalah bagaimana mereka dapat menciptakan sebuah bentuk akuntansi yang dapat mengarahkan perilaku manusia ke arah perilaku yang etis dan ke arah terbentuknya peradaban bisnis yang ideal. Menurut Triyuwono dikatakan bahwa bisnis yang ideal yaitu peradaban bisnis dengan nilai humanis, emansipatoris, transendental, dan teologikal.

Sesuai dengan sifat bisnis tersebut, maka akuntansi syariah juga harus memiliki sifat humanis, emansipatoris, transendental, dan teologikal. Lebih jauh Triyuwono menguraikan sifat-sifat tersebut sebagai berikut. Nilai humanis akuntansi syariah adalah, bahwa akuntansi yang dibentuk ini ditujukan untuk memanusiakan manusia, atau mengembalikan manusia pada fitrahnya yang suci. Sebab menurut penelitian Morgan (1988) diketahui, bahwa praktek akuntansi telah mengakibatkan manusia menjadi less humane. Atau dengan istilah lain, bahwa masyarakat kita sedang mengalami proses dehumanisasi.

Sifat humanis akuntansi atau bentuk bisnis lainnya tersebut, diharapkan dapat mendorong perilaku manusia itu sendiri. Sehingga manusia semakin kuat kesadaran dirinya tentang hakikatnya. Melalui kesadaran diri tentang hakikat manusia ini merupakan landasan bagi manusia dalam memberi nilai emansipatoris pada akuntansi syariah. Sifat ini berarti bahwa tidak lagi berlaku bentuk dominasi atau penindasan dari satu pihak ke pihak yang lain. Dengan kata lain, informasi yang diberikan oleh akuntansi syariah adalah berupa pembebasan dan tertuju pada semua pihak serta tidak menyepelekan pihak lain, atau akuntansi syariah akan berdiri pada posisi yang adil.

Oleh karena akuntansi syariah dibangun berdasarkan syariah Islam, maka nilai transendental akuntansi syariah terlihat 
jelas. Hal ini merupakan indikasi yang kuat bahwa akuntansi syariah tidak semata-mata menjadi instrumen bisnis yang bersifat profan, tetapi juga sebagai instrumen yang melintas batas dunia profan. Dengan demikian, yang selama ini akuntansi dikenal sebagai alat pertanggungjawaban kepada pemilik perusahaan, maka akuntansi syariah adalah lebih dari itu, yaitu pertanggungjawaban kepada stakeholders dan Tuhan. Dengan sifat ini, dalam melakukan praktek bisnis dan akuntansi maka seseorang yang terlibat akan selalu menggunakan, atau tunduk dan pasrah terhadap kehendak Tuhan (etika syari'ah). Nilai semacam inilah yang dimaksud dengan teologikal. Artinya praktek akuntansi syariah akan mengantarkan pelakunya secara riil teraktualisasi dalam bentuk kegiatan menciptakan dan menyebarkan kesejahteraan bagi seluruh alam.

Mengapa akuntansi syariah muncul ke permukaan, padahal akuntansi Barat telah mengakar dalam inti bisnis masyarakat? Ternyata, para perintis akuntansi, khususnya bidang ekonomi politik akuntansi, memiliki beberapa keraguan tentang pandangan akuntansi modern yang akan menunjukkan penting. Mereka mempertanyakan peranan akuntansi untuk menghubungkan masalahmasalah sosial dengan masalah organisasi dan individual. Sebab perhatian terhadap akuntansi dalam masyarakat tidak sama di mana-mana kendatipun di antara masyarakat (negara-negara) yang menganut konsep itu seluruhnya.

Teori akuntansi harus mengkaji akuntansi di masyarakat dimana ia dipraktekkan. Hal ini berarti bahwa sikap ini mungkin merupakan suatu cara untuk melahirkan aturan-aturan akuntansi. Sebagaimana dijelaskan oleh Gambling, oleh karena tidak adanya aturan akuntansi, maka akuntansi Barat tidak membahas mengenai aturan apa pun yang berkaitan dengan masalah organisasi (perusahaan), yang berhubungan dengan masyarakat dan individu. Aturan semacam itu bisa disebut sebagai suatu bahasan dalam teori akuntansi sekarang. Di pihak lain persyaratan masyarakat mengenai akuntansi secara kuantitatif meningkat juga.

Akuntansi syariah tidak menolak pendapat bahwa akuntansi menyesuaikan kelompok- kelompok yang berkepentingan. Tetapi Akuntansi Syariah menyangkut masalah ekonomi, masalah politik, dan juga masalah akuntansi. Dengan kata lain, fungsinya sebagai bagian syariah. Dalam konteks itu harus diterima bahwa akuntansi Islam (syariah) memainkan peranan untuk menyesuaikan kelompok-kelompok yang berkepentingan dalam masyarakat. Secara singkat dapat dijelaskan, bahwa teori akuntansi syariah dipelajari sebagai suatu sistem akuntansi dan pada saat yang sama ditafsirkan sebagai sesuatu yang berhubungan dengan manajemen, ekonomi, hukum, politik, dan agama.

\section{Praktek Akuntansi Syariah}

Kemunculan dan perkembangan lembaga keuangan Islam di Indonesia yang sangat fenomenal, telah memicu lahirnya diskusi - diskusi serius lebih lanjut, mulai dari produk atau jasa yang ditawarkan, pola manajemen lembaga, sampai kepada pola akuntansinya. Aspek akuntansi badan usaha memang selalu menarik untuk dijadikan kajian dan bahan diskusi, apalagi bila badan tersebut mempunyai kekhasan tersendiri seperti halnya lembaga keuangan Islam. Menariknya akuntansi untuk dibahas, tentu karena adanya beberapa alasan. Pertama: akuntansi selama ini dikenal sebagai alat komunikasi, atau sering diistilahkan sebagai bahasa bisnis. Kedua, akuntansi sering diperdebatkan apakah ia netral atau tidak. Ketiga, akuntansi sangat dipengaruhi oleh lingkungan (politik, ekonomi, budaya) dimana ia dikembangkan; dan Keempat, akuntansi mempunyai peran sangat penting, karena apa yang dihasilkannya, bisa menjadi sumber atau dasar legitimasi sebuah keputusan penting dan menentukan.

Dengan pertimbangan faktor-faktor di atas, maka manakala lembaga keuangan Islam ramai dibicarakan, timbul pertanyaan seperti, bagaimana dengan akuntansi yang diterapkan oleh lembaga keuangan Islam? 
Apakah lembaga keuangan Islam boleh memakai akuntansi yang sekarang dikenal, atau harus menerapkan praktik akuntansi yang berbeda? Jika demikian, bagaimana bentuk akuntansi yang lebih Islami atau dapat diterima syariah? Sejauh mana akuntansi syariah berbeda dengan praktik akuntansi yang sekarang ada?

Pada tatanan teknis operasional, akuntansi syariah adalah instrumen yang digunakan untuk menyediakan informasi akuntansi yang berguna bagi pihak-pihak yang bekepentingan dalam pengambilan keputusan ekonomi. Persoalan yang muncul adalah bagaimana keputusan ekonomi yang sekiranya tidak menyimpang dari syariah Islam atau dapat diterima oleh Islam. Untuk itu, dalam pembahasan teori maupun praktek ekonomi (termasuk di dalamnya bidang manajemen atau akuntansi, misalnya) hendaknya dibahas dari sudut Islam, bukan sekedar dari sudut agama. Dalam kaitan ini, Qardhawi menyarankan, agar: "kita tidak membahas ekonomi dari sudut agama, akan tetapi (membahas) ekonomi dari sudut Islam

Dengan demikian jelas, bahwa upaya kita menemukan format teori maupun praktek ekonomi (manajemen dan akuntansi Islam) harus dilandaskan pada Islam sebagai sesuatu yang integral. Kemudian diturunkan sampai pada bagian yang lebih bersifat operasional seperti bagaimana pengaturan zakat, bagaimana persoalan riba, dan sebagainya. Hal-hal demikian inilah yang merupakan ciri-ciri khas dari pengembangan bidang/aspek kehidupan yang Islami, sesuai dengan syariah Islam.

Sebagai turunan dari uraian di atas, barangkali uraian tentang keputusan ekonomi yang dihasilkan oleh akuntansi syariah adalah bercirikan sebagai berikut: menggunakan nilai etika sebagai dasar bangunan akuntansi, memberikan arah pada, atau menstimulasi timbulnya, perilaku etis, bersikap adil terhadap semua pihak, menyeimbangkan sifat egoistik dengan altruistik, dan mempunyai kepedulian terhadap lingkungan.

Berdasarkan landasan dan ciri-ciri tersebut di atas, maka diharapkan akuntansi syariah akan mempunyai bentuk yang lebih sempurna bila dibandingkan dengan akuntansi konvensional. Sebab melalui ciri-ciri tersebut tercermin sesuatu yang sarat akan pertanggungjawaban, nilai-nilai sosial dan jelas. Mengapa harus demikian? Sebab disadari bahwa pada tatanan yang lebih teknis, yaitu dalam bentuk laporan keuangan, akuntansi syariah masih mencari bentuk. Di dalam tesis ini, bentuk konkrit akuntansi syariah secara utuh belum dapat ditampilkan, sebab untuk sampai pada tataran praktek dan bentuk laporan keuangan yang utuh memerlukan dukungan teori yang lengkap dan kuat.

Di samping itu, usaha membentuk model akuntansi syariah bukan suatu langkah "tambal sulam" yang dilakukan untuk memperbaiki akuntansi konvensional. Akan tetapi, upaya ini harus dilakukan dengan pijakan filosofis yang sangat mendasar. Di balik itu, pemikiran filosofis tidak akan banyak memberikan perubahan, bila tidak dilanjutkan pada pemikiran teoritis dan teknis.kesimpulan bahwa untuk pengukuran zakat dari harta dan aset yang dimiliki oleh perseorangan maupun perusahaan, harus digunakan pendekatan lain.

Akuntansi Syariah sebagai Refleksi Akuntansi Sosial dan Pertanggungjawaban. Wujud akuntansi syariah tercermin dalam kiasan atau metafora "amanah". Metafora amanah dapat diturunkan menjadi metafora "zakat", atau dengan kata lain, realitas organisasi akuntansi syariah adalah realitas organisasi yang dimetaforakan dengan zakat. Metafora ini membawa konsekuensi pada organisasi bisnis, yaitu organisasi bisnis yang tidak lagi berorientasi pada laba (profitoriented) atau berorientasi pada pemegang saham (stakeholders-oriented), tetapi berorientasi pada zakat (zakat-oriented). Dengan orientasi zakat, perusahaan berusaha untuk mencapai "angka" pembayaran zakat yang tinggi. Dengan demikian, laba bersih (net profit) tidak lagi menjadi ukuran kinerja (performance) perusahaan, tetapi sebaliknya zakat menjadi ukuran kinerja perusahaan.

Dilihat dari nilai praktis akuntansi, akuntansi syariah dengan metafora amanah 
dan berorientasikan zakat merupakan metafora akuntansi yang sangat fokus pada orientasi sosial dan pertanggungjawaban. Sebab akuntansi (bisnis) yang bermetaforakan amanah biasanya memiliki nilai praktis yang bersifat humanis, emansipatoris, transcendental dan teleologikal. Nilai praktis ini, menunjukkan sifat amanah bagi para pelaku

Nilai praktis akuntansi syariah yang berorientasi zakat tersebut, menimbulkan konsekuensi ontologis, bahwa akuntan secara kritis harus mampu membebaskan manusia dari ikatan realitas (peradaban) manusia beserta jaringan-jaringan kuasanya, untuk kemudian memberikan atau menciptakan realitas alternatif dengan seperangkat jaringan - jaringan kuasa Ilahi yang mengikat manusia dalam hidup sehari-hari. Dengan istilah lain, dapat terbangunnya ontologi tauhid. Dengan cara demikian, realitas alternatif diharapkan akan dapat membangkitkan kesadaran diri secara penuh akan kepatuhan dan ketundukan seseorang pada kuasa Ilahi. Melalui kesadaran diri ini, seseorang akan selalu merasa kehadiran Tuhan dalam dimensi waktu dan tempat di mana berada.

Jadi, dengan akuntansi syariah, realitas sosial yang dikonstruk mengandung nilai tauhid dan ketundukan pada jaringanjaringan kuasa Ilahi; yang semuanya dilakukan dengan meta-perspective, yaitu perspektif khalifat-ulLah fil ardh, suatu cara pandang yang sadar akan hakikat diri manusia dan tanggungjawab kelak di kemudian hari di hadapan Allah SWT. Dalam skala mikro, realitas sosial dapat diidentikan dengan realitas organisasi, yaitu realitas yang diciptakan dalam organisasi bisnis, sehingga terbentuk kondisi seperti yang dicitakan dalam ontologi tauhid tadi. Bila realitas organisasi yang demikian tercipta, maka sangat mungkin bahwa realitas tersebut akan menebarkan rahmat, yang tidak saja bagi mereka yang secara aktif terlibat dalam operasi organisasi, tetapi juga kepada masyarakat luas dan lingkungan alam sekitarnya.

Islam adalah agama yang rahmatan lil'alamiin. Artinya ajaran Islam akan dapat diterapkan atau dipakai siapa saja, dan dimana saja. Rahmatan lil 'alamiin adalah sebuah konsep yang mengandalkan pada konsep keadilan. Keadilan merupakan isi kandungan yang tidak dapat dihilangkan dari keyakinan Islam. Sehingga kondisi ideal masyarakat Islam tidak akan dapat tercapai apabila keadilan tidak ditegakkan. Islam ingin menjinakkan semua perilaku dzalim dari masyarakat. Termasuk di dalamnya adalah perilaku dzalim masyarakat bisnis. Perilaku dzalim adalah perilaku-perilaku dalam bentuk diskriminasi, ketidakadilan, eksploitasi, tekanan dan perilaku sewanang-wenang yang dengan dengan perilaku ini dapat merugikan orang lain.

Pertanyaan mendasar yang muncul adalah kapan suatu keadilan dalam suatu masyarakat terwujud? Keadilan masyarakat merupakan keadilan ideal, dimana masyarakatnya dapat hidup dengan layak dalam berbagai bidang. Tidaklah mungkin untuk mendapatkan masyarakat Islam yang ideal sementara keadilan tidak ditegakkan.

Berdasarkan paparan di atas, satu hal yang tidak dapat dihindari dari keyakinan Islam bahwa manusia merupakan khalifah (wakil) Tuhan, dan manusia harus mengatur hidup sesuai dengan status mereka. Pengarahan-pengarahan yang terkandung dalam ajaran-ajaran Islam adalah dalam rangka membantu merealisasikan tujuan ini. Para ulama sangat percaya bahwa kesejahteraan umat dan peringanan mereka dari beban hidup yang berat merupakan tujuan dasar syariah. Pandangan ini, jika dilihat dari sudut pandang ekonomi merupakan penekanan pada penciptaan kelayakan ekonomi melalui pemenuhan kebutuhan dasar dan penciptaan keadilan sosial-ekonomi.

Pembicaraan mengenai akuntansi Islam haruslah dipahami sebagai sebuah alat yang memiliki orientasi sosial. Mengapa demikian? Sebab akuntansi Islam tidak hanya sebagai alat untuk menterjemahkan fenomena ekonomi dalam bentuk ukuran moneter tetapi juga sebagai suatu metode untuk menjelaskan bagaimana fenomena ekonomi itu berjalan dalam masyarakat Islam. Hal ini tidak sama dengan perbedaan antara akuntansi deskriptif 
dengan akuntansi normatif. Akuntansi deskriptif ini bertujuan untuk menawarkan akuntansi yang cocok dengan tujuan tertentu. Jika tujuan berbeda, maka pasti norma juga berbeda.

Secara jelas akuntansi Islam yang diterapkan pada lembaga keuangan syariah adalah upaya penerapan akuntansi yang menyangkut masalah ekonomi, masalah politik, dan juga masalah akuntansi itu sendiri. Dengan kata lain, fungsinya sebagai bagian dari syariah. Dalam konteks itu harus diterima, bahwa akuntansi syariah memainkan peranan untuk menyesuaikan kelompokkelompok yang berkepentingan bisnis dalam masyarakat. Di sinilah letak posisi sosial dari akuntansi Islam.

Akuntansi berorientasi sosial adalah sebuah akuntansi yang menyajikan atau mengungkap dampak sosial perusahaan terhadap masyarakat. Dengan demikian, pengungkapan perusahaan tentang dampak sosialnya terhadap masyarakat sebagai suatu kewajiban. Jika ihwalnya adalah berkaitan dengan masalah kewajiban sosial, maka cara baku untuk pengembangan akuntansi yang dapat diterima oleh seluruh umat -sesuai dengan sifat rahmatan lil 'alamiin ajaran Islam- adalah dengan cara memperluas konsep dasar sistem zakat.

Mengapa harus memperluas konsep dasar sistem zakat? Sebab sebagaimana diuraikan pada bagian sebelumnya, bahwa zakat sebagai suatu institusi yang memiliki perspektif sosial harus dikenakan kepada seluruh aktiva perusahaan maupun perorangan. Walaupun meski harus dilihat lebih dahulu apakah zakat dikenakan kepada aktiva lancar atau tidak lancar. Mengingat zakat merupakan pengeluaran yang harus dibayarkan setelah mencapai nishab. Nishab terjadi apabila harta yang dimiliki seseorang atau perusahaan itu bertambah dan bertambah, sehingga yang bersangkutan akan dikenai pengeluaran zakat apakah sebanyak 2,5\%, 5\% atau 10\%, tergantung pada jenis aktiva yang menghasilkan yang dimiliki oleh seseorang atau perusahaan. Dengan kata lain, zakat dalam akuntansi dikenakan pada aktiva lancar.
Oleh karena orientasi sosial akuntansi syariah adalah dibebankan kepada perluasan konsep zakat, maka kias (metafora) organisasi akuntansi harus dirujukkan pada orientasi zakat, bukan lagi pada orientasi laba atau stakeholder oriented. Inilah yang lebih lanjut dikatakan oleh Triyuwono sebagai organisasi bermetaforakan "amanah". Orientasi zakat mengandung pengertian luas dan komprehensif. Sebab zakat bukan sekedar dinyatakan dalam bentuk angka-angka prosentase, akan tetapi melalui zakat dapat diketahui kinerja perusahaan. Yaitu semakin tinggi zakat yang dikeluarkan oleh perusahaan berarti semakin besar laba yang di dapat perusahaan.

Lebih tegas lagi dapat dikatakan, bahwa penggunaan kiasan (metafora) zakat untuk menciptakan realitas organisasi mempunyai beberapa makna. Menurut Triyuwono ada lima makna realitas organisasi tersebut, yaitu

1) Ada transformasi dari pencapaian laba bersih (yang maksimal) ke pencapaian zakat.

2) Karena yang menjadi tujuan adalah zakat, maka segala bentuk operasi perusahaan (akuntansi) harus tunduk pada aturan main (rules of game) yang ditetapkan dalam syariah.

3) Zakat mengandung perpaduan karakter kemanusiaan yang seimbang antara karakter egoistik dan altruistik/sosial.

4) Zakat mengandung nilai emansipatoris.

5) Zakat adalah jembatan penghubung antara aktivitas manusia yang bersifat duniawi dan ukhrowi.

Apabila dianalisis lebih lanjut, pemikiran di atas jelas menunjukkan orientasi sosial yang jelas dari zakat. Pada saat zakat ditempatkan sebagai metofora organisasi atau zakat sebagai inti organisasi akuntansi.

Sebagaimana makna pertama: ada transformasi dari pencapaian laba bersih (yang maksimal) ke pencapaian zakat. Hal ini berarti bahwa pencapaian laba bukan merupakan tujuan akhir perusahaan, tetapi hanya sekedar tujuan antara. 
Oleh karena zakat menjadi tujuan akhir, maka segala bentuk operasi perusahaan (akuntansi) harus tunduk pada aturan main (rules of game) yang ditetapkan dalam syariah. Sebagai contoh: kapan seseorang atau perusahaan mengeluarkan zakat sebagai orientasi sosial perusahaan; berapa persen zakat yang dikeluarkan oleh seseorang atau perusahaan; dan siapa saja yang harus diberi zakat. Kesemuanya ini dijalankan mengikuti aturan-aturan main yang ada dalam syariah Islam. Penyimpangan terhadap aturan atau hukum syariah menjadikan tidak sahnya tujuan zakat.

Zakat mengandung perpaduan karakter kemanusiaan yang seimbang antara karakter egoistik dan altruistik/sosial. Artinya, bahwa seseorang mengeluarkan zakat berarti ia telah mementingkan lebih dahulu kepentingan orang lain daripada kepentingan pribadinya. Karakter egoistik mencerminkan bahwa seseorang atau perusahaan tetap diperkenankan untuk mencari laba (namun tetap dalam bingkai Syariah), dan kemudian sebagian dari laba (dan kekayaan bersih) yang diperoleh dialokasikan sebagai zakat. Sedangkan altruistik atau sosial mempunyai arti bahwa perusahaan juga mempunyai kepedulian yang sangat tinggi terhadap kesejahteraan manusia dan alam lingkungan yang semuanya ini tercermin dalam zakat itu sendiri.

Zakat mengandung nilai emansipatoris. Hal ini berarti, bahwa zakat sebagai lambang pembebas manusia dari ketertindasan ekonomi, sosial, dan intelektual, serta pembebasan alam dari penindasan dan eksploitasi manusia. Akhirnya, zakat adalah jembatan penghubung antara aktivitas manusia yang bersifat duniawi dan ukhrowi. Hal ini berarti, bahwa zakat sebagai jembatan, memberikan kesadaran ontologis bagi diri manusia, karena segala bentuk kegiatan profan selalu berkait erat dengan kehidupan manusia dihadapan Allah kelak di akhirat.

Dari pemikiran di atas menunjukkan, bahwa semua perangkat organisasi yang akan disusun harus benar- benar merefleksikan zakat sebagai suatu kias (metafora). Hal ini menunjukkan adanya bentuk transformasi. Transformasi ini tidak saja akan mempengaruhi perilaku manajemen, stockholders, karyawan, dan masyarakat sekelilingnya, tetapi juga perangkat informasi. Perangkat informasi yang ada dalam perusahaan inilah yang biasanya berbentuk akuntansi yang digunakan oleh organisasi yang bersangkutan.

Gambaran di atas harus dijadikan pijakan dalam pengembangan format akuntansi syariah, yang berdimensikan pertanggungjawaban (accountability). Dimensi pertanggungjawaban dalam akuntansi syariah adalah memiliki cakupan yang luas. Jadi pertanggungjawaban ini bukan hanya pertanggungjawaban atas uang (finansial) yang digunakan dalam melaksanakan kegiatan, akan tetapi pertanggungjawaban ini harus mampu meningkatkan tanggungjawab secara horizontal dan vertikal. Pertanggungjawaban horizontal tertuju pada masyarakat, pemerintah dan kepatuhan pada peraturan. Sementara pertanggungjawaban vertikal adalah tertuju pada transendensi aktivitas (finansial, dan sebagainya) kepada Dzat yang memberikan tanggungjawab. Secara rinci, sehubungan dengan kepentingan-kepentingan tersebut Hadjisarosa mengidentifikasi sebagai berikut:

1) Kelangsungan hidup dan perkembangan perusahaan

2) Pelanggan

3) Pemilik modal

4) Karyawan

5) Rekanan

6) Pemerintah

7) Masyarakat, dan

8) Pelestarian lingkungan.

Kendatipun telah terdapat delapan kepentingan yang harus diperhatikan dalam melakukan pertanggungjawaban atas kondisi dan informasi akuntansi, namun delapan hal tersebut hanyalah baru sebatas pada dimensi horizontal. Timbul pertanyaan, dimanakah letak dimensi vertikalnya? Jawabanya adalah ada pada dimensi zakat. Zakat sebagai manifestasi pertanggungjawaban hamba yang melakukan perbuatan/aktivitas bisnis yang 
dapat diaudit kemudian dipertanggungjawabkan kesucian modal kepada Dzat pemberi modal. Dimensi inilah yang merupakan dimensi paling tinggi.

Perihal yang berkaitan dengan masalah pertanggungjawaban secara vertikal secara syariah diatur oleh hukum-hukum Allah yang terdapat dalam al-Qur'an dan sunnah Rasul. Persoalan berikutnya adalah bagaimana upaya untuk meningkatkan accountability yang berkaitan dengan dimensi horizontal. Kiranya pandangan Lee Parker dapat dijadikan rujukan atau petunjuk bagi peningkatan accountability, sebagai berikut:

1) Mengintegrasikan antara data keuangan dan non keuangan

2) Penilaian terhadap hasil yang bersifat keuangan dan non keuangan dengan membandingkannya dengan tujuan yang ingin dicapai.

3) Memperluas ruang lingkup tanggung jawab mencakup masyarakat/lingkungan

4) Laporan menyangkut tingkat kepatuhan perusahaan pada peraturan pemerintah dan standar akuntansi.

Dalam kerangka inilah, maka para akuntan dihadapkan pada kemajuan masa depan, yang penuh dengan ketidakpastian, ketidak beresan. Ketika kondisi ini terjadi, maka para akuntan harus menghormati nilai, norma dan etika teologis. Sehingga mereka mampu menampilkan dirinya sebagai akuntan yang dapat dipercaya, jujur, bertanggungjawab, dan sebagainya. Dengan demikian, akuntansi masa depan mestinya bukan hanya berorientasi pada pengambilan keputusan (decision making oriented) akan tetapi harus berorientasi pada pertanggungjawaban (accountability oriented). Sesuai dengan kata kunci pembicaraan ini, yaitu pertanggungjawaban, maka akuntansi pertanggungjawaban merupakan ciri khas akuntansi syariah. Sebab akuntansi pertanggungjawaban adalah akuntansi yang memberikan informasi yang adil dan bernar. Dengan demikian akuntansi syariah (Islam) yang memiliki unsur pengertian ekonomi, politik, dan agama memiliki kemungkinan besar untuk menunjukkan kunci ke arah akuntansi Pasca Newton.

\section{KESIMPULAN DAN SARAN \\ Kesimpulan}

Berdasarkan paparan di atas dapat disimpulkan hal-hal sebagai berikut: Pada tataran praktis akuntansi syariah adalah akuntansi yang berorientasi sosial dan pertanggungjawaban. Sebab akuntansi syariah dapat menyajikan atau mengungkap dampak sosial perusahaan terhadap masyarakat dan sekaligus menyajikan laporan pertanggungjawaban yang bersifat humanis, emansipatoris, transendental dan teologikal. Oleh karena itu, konsep dasar akuntansi syariah adalah bersifat zakat dan amanah oriented.

Perkembangan lebih lanjut akuntansi bukan sekedar dianggap sebagai ilmu (science) dan teknologi universal yang bebas nilai. Akan tetapi, akuntansi adalah produk sejarah yang merefleksikan budaya di tempat akuntansi dilaksanakan. Dengan kata lain, akuntansi syariah adalah ilmu dan teknologi universal yang tumbuh dan berkembang sesuai dengan perubahan yang terjadi di dalam lingkungannya, baik sosial, ekonomi, politik, peraturan perundangan, kultur, persepsi dan nilai (masyarakat) tempat akuntansi syariah diterapkan.

Akuntansi syariah adalah akuntansi yang dikembangkan bukan hanya dengan cara "tambal sulam" terhadap akuntansi konvensional, akan tetapi, merupakan pengembangan filosofis terhadap nilai-nilai al-Qur'an yang diturunkan ke dalam pemikiran teoritis dan teknis akuntansi. Oleh karena itu, secara substantif akuntansi syariah bersifat humanis, emansipatoris, transendental dan teologikal.

\section{Saran}

Bahwa dalam pelaksanaan kegiatan perusahaan, sebaikanya sedikit dari hasil laba/profit perusahaan baiknya selalu digunakan untuk zakat. Pemerintah yang dalam hal ini bertindak sebagai salah satu stakeholder harus benar - benar memberikan sangsi kepada perusahaan yang tidak mengeluarkan atau tidak melakukannya. Karena zakat bisa termasuk dalam salah satu kegiatan CSR perusahaan. 
DAFTAR PUSTAKA

Adnan, M. Akhyar (1996). "(Teknologi) Akuntansi Syariah", Kertas Kerja Seminar Nasional Hari Teknologi Nasional, Yogyakarta.

Baswir, Revrisond. (1996). Akuntansi dan Ideologi, Kertas Kerja pada SeminarNasional Harteknas, Yogyakarta 27 Desember.

Cooper, D.J. dan T.M. Hopper, (1987). Critical Studies in Accounting, Accounting Organization and Society. New York: Prentice-Hall International, Inc.

Gaffikin, M.J.R. (1998). Accounting Methodology and The Work of R.J. Chambers. New York: Garland Publishing, Inc.

Gambling, Trevor E. (1971). Toward a General Theory of Accounting. International Journal of Accounting Education and Research, Vol. 7, No. 1 Fall.

Gilling, D.M. (1996). Accounting and Social Change, International Journal of Accounting, Education and Research, Vol. 1, No.2 Spring.

Hadjisarosa, Poernomosidi, (1997), Makalah Kursus Singkat dan Lokakarya Ekonomi Islam II Sekolah Tinggi Ilmu Syari'ah, Yogyakarta, tanggal $18-21$ Agustus , Hal. 4.

Harahap, Sofyan Syafri, (1997). Akuntansi Islam, Jakarta: Bumi Aksara, Hayashi, Toshikabu. (1995). On Islamic Accounting, Tokyo: Institute of Middle Eastern Studies, International University of Japan.

Kuntowidjojo, Paradigma Islam: Interpretasi untuk Aksi, Bandung: Penerbit Mizan, Laughlin, R.C., T. et. al. (1989). Contextual Studies of Accounting and Auditing: An Introduction, Accounting, Auditing and Accountability. Journal.

Lodh, Sudhir C. (1996). Critical Studies in Accounting Research, Rationality and Habermas: A Methodological
Reflection, Paper to be Presented at the Fourth CPA Conference. New York City, 26-28 April

Neimark, M. and Tinker, (1996). The Social Construction of Management Control System. New York: Prentice-Hall.

Parker, Lee D. (1994). Here's to An Accountable Future. Australia: International Accounting Conference, November 14-16.

Shahata, Shauqi Ismail. (1987). Financial Accounting from the Islamic Point of View, Cairo: Alzahra al-A'lam alA'rabi, Hal. 9.

Triyuwono, Iwan (1996). Organisasi, Akuntansi, dan Spiritualisme Islam, Makalah Stadium General Mahasiswa Syari'ah Banking Institute Yoyakarta, tanggal 28 September, (19970 Akuntansi Syariah: Implementasi Nilai Keadilan dalam Format Metafora Amanah, Kertas Kerja, Disampaikan dalam Kuliah Umum di Fakultas Syariah IAIN Walisongo Surakarta, 24 Februari.

M.J.R. Gaffikin, (1996), Shari'ate Accounting: An Ethical Construction of Accounting Knowledge The Fourth Critical Perspectives on Accounting Symposium, 26-28 April 1996, New York City, 